\title{
Mortality of workers potentially exposed to organic and inorganic brominated chemicals, DBCP, TRIS, $\mathrm{PBB}$, and DDT
}

\author{
O WONG, ${ }^{1}$ W BROCKER, ${ }^{2}$ H V DAVIS, ${ }^{2}$ AND G S NAGLE ${ }^{3}$
}

From the Environmental Health Associates, 'Berkeley, California 94704, Velsicol Chemical Corporation, ${ }^{2}$ Chicago, Illinois 60611, and Bristol-Meyers, ${ }^{3}$ Syracuse, NY 13201, USA

ABSTRACT A historical prospective mortality study was conducted on 3579 white male workers employed between 1935 and 1976 with potential exposures to brominated compounds including 1,2-dibromo-3-chloropropane (DBCP), Tris (2,3-dibromopropyl) phosphate, polybrominated biphenyls (PBB), various organic and inorganic bromides, and DDT. The vital status as of 31 December 1976 was determined for $3384(95 \%)$ of these workers: $2806(79 \%)$ were still living and $578(16 \%)$ had died. Death certificates were obtained for 541 deaths (94\% of all deaths). The mortality experience of the entire cohort and several subcohorts was compared with that of United States white men adjusted for age and calendar time. The comparison statistic was the commonly used standardised mortality ratio (SMR). Historical industrial hygiene data were not available, and the workers were classified by their work areas or departments in order to estimate their potential exposures. Overall mortality for the entire cohort and several subgroups was significantly lower than expected. For the entire cohort, significant mortality deficits were observed in diseases of the circulatory system, non-malignant respiratory disease, and diseases of the digestive system. On the other hand, mortality from diabetes mellitus was significantly raised for the cohort. No significant overall or cause-specific mortality excess was detected among employees potentially exposed to either TRIS or DDT. A significant mortality excess due to diseases of the circulatory system was observed among workers potentially exposed to DBCP. Mortality from testicular cancer was significantly higher than expected among those potentially exposed to other organic bromides. The common potential exposure of those who had died of testicular cancer was methyl bromide. Owing to the lack of accurate historical exposure information and the fact that many workers were potentially exposed to a multitude of chemicals, it is difficult to draw definitive statements on the causations of the observed mortality excesses.

Several brominated compounds, such as 1,2dibromo-3-chloropropane (DBCP), Tris (2,3dibromopropyl) phosphate, and polybrominated biphenyls (PBB), are suspected of causing cancers in animals and sterility in man. Up to now, no human mortality data on these chemicals have been reported. Because of these concerns, an epidemiological study of chemical workers potentially exposed to these and other brominated chemicals was conducted. The primary goal of the study was to determine the cause-specific mortality experience of these workers and to relate the mor-

Received 9 November 1982 Accepted 10 January 1983. tality to their potential exposures. The general findings of the study have been presented at a recent conference. ${ }^{\text {The }}$ present report will focus on specific chemicals. For completeness, however, the background of the study and some relevant general results will be briefly reviewed.

\section{Methods and materials}

The cohort consisted of chemical workers who had been employed between 1935 and 1976 at three manufacturing plants (two in Michigan and one in Arkansas) and a research establishment in Michigan, where potential exposure to brominated chemicals existed. These workers were identified by 
personnel records which generally included demographic information and an employment history. All personnel records were microfilmed or photocopied. The basic demographic information and the summary work history for each employee were then abstracted, coded, and entered into a computer.

Records of 3612 male workers, current and past, were collected. It was necessary to conduct a vital status follow up on $\mathbf{3 1 3 6}$ former employees who had terminated their employment before the study end date, 31 December 1976. The follow up consisted of a local inquiry and a search through the files of both the social security administration (SSA) and the motor vehicle bureaus of several states.

In the local follow up process the former employees or their families, their former coworkers, known friends, or other reliable sources were contacted and the vital status of the terminated employee ascertained. By this process, 1633 male workers were determined to be living and 338 were identified as dead. Whenever possible, information on place and date of death was obtained. Of the 1633 persons identified as living, $11 \%(180)$ were directly contacted, family members were contacted for $78 \%$ (1274), and coworkers, friends, or neighbours for $11 \%$ (179). For each of these 1633 individuals, the specifics of the follow up, including the names of people contacted, telephone numbers, and dates were documented. Thus the vital status could be verified independently.

Follow up using the SSA files was conducted for the remaining 1165 individuals whose vital status was not known. Names and social security numbers of the 338 identified as dead in the local follow up were also submitted to the SSA to obtain additional information on the date and place of death. Fifty one were excluded because of unknown social security numbers. A total of 1452 punched cards was submitted to the SSA.

From the 1452 social security numbers submitted, death claims had been filed for 543 employees and 657 were identified as living as of 31 December 1976. SSA was unable to provide any information for the remaining 252, of whom 24 had been previously identified by local follow up as dead. Because 51 names were not sent to SSA, there were $279(252$ $-24+51)$ subjects of unknown vital status at the completion of the SSA follow up.

Vital status was followed up through various state motor vehicle bureaux (MVB) after the SSA follow up was completed. Driving records were requested from the state MVB, and individuals were considered to be living if they had renewed their driver's licence after 31 December 1976. Additional follow up by telephone was conducted for those who had renewed their licence before the study cutoff date.
This was accomplished by obtaining their telephone number at the address listed on their driving record. Requests were made for a total of 266 individuals. Thirteen unknowns were excluded from this follow up because their dates of birth, a necessary identifier for MVB follow up, were unknown. It was necessary to conduct MVB follow up in seven states. As a result, 72 individuals were identified as living.

On completion of all vital status follow up, 207 were still of unknown vital status. Thirty three men (12 with unknown vital status and 21 alive) were excluded from final analysis because their dates of birth were not known, leaving a total of 3579 in the cohort. A total of $2806(78.4 \%)$ members of the study population was determined to be living on 31 December 1976, and $578(16.2 \%)$ were identified as dead (table 1). Death certificates were requested for these from the appropriate state vital statistics departments: $541(93.6 \%)$ were obtained. Of the 3579 men included in the analysis, $195(5.4 \%)$ had unknown vital status.

\section{Statistical analysis}

Causes of death were coded by a trained nosologist according to the rules in effect at the time of death and then converted into codes in the 8th revision of the International Classification of Diseases. ${ }^{2} \mathrm{~A}$ total of 541 deaths among the workers was coded.

The most common summary index for assessing the risk of death in a population studied prospectively is the standardised mortality ratio (SMR), which was used in this report. Race identification was not recorded on all employment records. According to the company, however, no blacks had worked at the larger Michigan plant, which contributed about $95 \%$ of the cohort. Therefore, the US white male age-cause-specific mortality rates for five year periods from 1935 to 1975 were used to calculate the expected deaths. The statistical analysis was performed using a standard computer program. ${ }^{3}$ Individuals with unknown vital status and those presumed dead but without a death certificate or a date of death were treated as lost to follow up on the last day of contact (termination). Deaths with a known

Table 1 Vital status of 3579 male workers potentially exposed to brominated chemicals

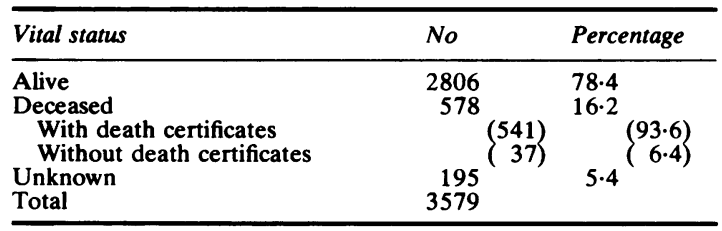


Table 2 Observed and expected deaths by cause, SMRs, and their $95 \%$ confidence limits for the entire cohort of 3579 male workers potentially exposed to brominated chemicals $(n=3579$, person-years $=68821 \cdot 7)$

\begin{tabular}{|c|c|c|c|c|c|}
\hline Cause of death (8th ICDA) & $\begin{array}{l}\text { Observed } \\
\text { deaths }\end{array}$ & $\begin{array}{l}\text { Expected } \\
\text { deaths }\end{array}$ & $S M R$ & $\begin{array}{l}\text { Lower } \\
\text { limit }\end{array}$ & $\begin{array}{l}\text { Upper } \\
\text { limit }\end{array}$ \\
\hline $\begin{array}{l}\text { All causes } \\
\text { All cancers (140-209) } \\
\text { Cancer of buccal cavity and pharynx }(140-149) \\
\text { Cancer of digestive system }(150-159) \\
\text { Cancer of stomach }(151) \\
\text { Cancer of large intestine (153) } \\
\text { Cancer of rectum (154) } \\
\text { Cancer of liver }(155) \\
\text { Cancer of pancreas (157) } \\
\text { Cancer of respiratory system (160-163) } \\
\text { Cancer of lung (162-163) } \\
\text { Cancer of prostate (185) } \\
\text { Cancer of testis (186) } \\
\text { Cancer of bladder (188) } \\
\text { Cancer of kidney (189) } \\
\text { Cancer of brain (191) } \\
\text { Lymphatic \& haematopoietic cancer (200-205) } \\
\text { Hodgkin's disease (201) } \\
\text { Leukaemia and aleukaemia (204-207) } \\
\text { Diabetes mellitus ( } 250) \\
\text { Diseases of nervous system and sense organs (390-458) } \\
\text { Diseases of circulatory system (393-398) } \\
\text { Chronic rheumatic heart disease (410-413) } \\
\text { Arteriosclerotic heart disease (inc CHD) (410-413) } \\
\text { Cerebrovascular disease (430-438) } \\
\text { Non-malignant respiratory disease (470-527) } \\
\text { Diseases of digestive system (530-587) } \\
\text { Cirrhosis of liver (581) } \\
\text { Accidents, poisonings, and violence (E800-E999) }\end{array}$ & $\begin{array}{r}543 \\
112 \\
3 \\
18 \\
2 \\
6 \\
2 \\
3 \\
5 \\
46 \\
42 \\
11 \\
2 \\
3 \\
4 \\
5 \\
13 \\
1 \\
9 \\
19 \\
6 \\
258 \\
4 \\
184 \\
37 \\
26 \\
15 \\
4 \\
79\end{array}$ & $\begin{array}{r}614.34 \\
110.29 \\
3.73 \\
32.58 \\
7.07 \\
9.78 \\
3.93 \\
2.41 \\
6.00 \\
34.07 \\
31.95 \\
6.71 \\
1.04 \\
3.15 \\
2.76 \\
3.78 \\
11.73 \\
1.95 \\
4.83 \\
8.65 \\
5.59 \\
309.03 \\
7.54 \\
209.87 \\
42.03 \\
32.32 \\
31.44 \\
15.83 \\
77.27\end{array}$ & $\begin{array}{c}88 \dagger \\
102 \\
81 \\
55 \dagger \\
28 \\
61 \\
51 \\
124 \\
83 \\
135 \\
131 \\
164 \\
193 \\
92 \\
145 \\
132 \\
111 \\
51 \\
187 \\
220 \dagger \\
107 \\
83 \dagger \\
53 \\
88 \\
88 \\
80 \\
48 \dagger \\
25 \dagger \\
102\end{array}$ & $\begin{array}{r}81 \\
84 \\
16 \\
33 \\
3 \\
22 \\
6 \\
25 \\
27 \\
99 \\
95 \\
82 \\
22 \\
19 \\
39 \\
43 \\
59 \\
1 \\
85 \\
132 \\
39 \\
74 \\
14 \\
75 \\
62 \\
53 \\
27 \\
7 \\
81\end{array}$ & $\begin{array}{r}96 \\
122 \\
235 \\
87 \\
102 \\
134 \\
184 \\
363 \\
195 \\
180 \\
178 \\
293 \\
697 \\
270 \\
370 \\
309 \\
190 \\
286 \\
354 \\
343 \\
234 \\
94 \\
136 \\
101 \\
121 \\
118 \\
79 \\
65 \\
127\end{array}$ \\
\hline
\end{tabular}

tStatistically significant at 0.01 level.

date of death but without a death certificate were included in the overall mortality analysis but not in the cause-specific analysis.

\section{OVERALL ANALYSIS}

Table 2 lists the observed deaths, expected deaths, and SMRs by cause for the entire cohort. A total of 543 deaths was included in the analysis (two with date of death but no death certificate). Since 614.34 deaths were expected, the overall SMR is 88 . This $12 \%$ deficit is statistically significant at the 0.01 level.

A total of 112 deaths was attributed to malignant neoplasms, practically identical with the expected number of 110.29 based on the United States white male cancer mortality rates. The site-specific cancer mortality observed in this cohort of male workers deviated from that expected, although only in one case is the deviation statistically significant at the 0.05 level. For cancer of the digestive system, 18 deaths were observed, compared with an expected 32.58. The corresponding SMR is $55(\mathrm{p}<0.01)$. The deficit appears to have come from cancer of the stomach.

None of the other site-specific cancer SMRs examined is statistically significant. It should be noted, however, that 46 deaths from cancer of the respiratory system occurred, while only 34.07 were expected. The corresponding SMR of 135 is very close to statistical significance $(p=0 \cdot 05)$. In addition, there were 11 observed deaths from prostatic cancer compared with 6.71 expected $(\mathrm{SMR}=164$, non-significant); and nine observed deaths from leukaemia compared with 4.83 expected (SMR $=187$, non-significant).

For diabetes mellitus, 19 deaths were observed, with only 8.65 expected. The corresponding SMR is 220 , statistically significant at the 0.01 level. Additional analysis and discussion on diabetes mellitus will be given below.

For diseases of the circulatory system, the cohort as a whole experienced only $83 \%$ of the expected (SMR $=83, \mathrm{p}<0.01)$, and for diseases of the digestive system, the SMR is 48 (15 observed $v$ 31.44 expected, $\mathrm{p}<0.01$ ).

Mortality was also analysed by duration of employment, year of hire, and latency. The results have been reported elsewhere, ${ }^{1}$ and will not be repeated here.

\section{ANALYSIS FOR SPECIFIC CHEMICALS}

In an attempt to correlate mortality with exposure, a job/department title dictionary consisting of all job/department titles encountered during the coding process was created. A copy of the dictionary was given to the company industrial hygienists and plant 
Table 3 Observed and expected deaths by cause, SMRs, and their $95 \%$ confidence limits for male workers potentially exposed to $D B C P$ on a routine or non-routine basis at all four plants $(n=1034$, person-years $=11510 \cdot 5)$

\begin{tabular}{|c|c|c|c|c|c|}
\hline Cause of death (8th ICDA) & $\begin{array}{l}\text { Observed } \\
\text { deaths }\end{array}$ & $\begin{array}{l}\text { Expected } \\
\text { deaths }\end{array}$ & $S M R$ & $\begin{array}{l}\text { Lower } \\
\text { limit }\end{array}$ & $\begin{array}{l}\text { Upper } \\
\text { limit }\end{array}$ \\
\hline $\begin{array}{l}\text { All causes } \\
\text { All cancers (140-209) } \\
\text { Cancer of digestive system }(150-159) \\
\text { Cancer of stomach (151) } \\
\text { Cancer of large intestine (153) } \\
\text { Cancer of rectum }(154) \\
\text { Cancer of pancreas (157) } \\
\text { Cancer of respiratory system (160-163) } \\
\text { Cancer of lung }(162-163) \\
\text { Cancer of prostate }(185) \\
\text { Cancer of testis (186) } \\
\text { Cancer of bladder (188) } \\
\text { Diabetes mellitus (250) } \\
\text { Diseases of circulatory system (393-398) } \\
\text { Arteriosclerotic heart disease (inc CHD) (410-413) } \\
\text { Cerebrovascular disease (430-438) } \\
\text { Non-malignant respiratory disease (470-527) } \\
\text { Diseases of digestive system (530-587) } \\
\text { Diseases of genitourinary system (580-629) } \\
\text { Accidents, poisonings, and violence (E800-E999) } \\
\text { Accidents (800-949) } \\
\text { Motor vehicle accidents (810-827) } \\
\text { Suicide (950-959) }\end{array}$ & $\begin{array}{r}74 \\
19 \\
5 \\
1 \\
1 \\
2 \\
1 \\
9 \\
7 \\
1 \\
1 \\
1 \\
2 \\
38 \\
26 \\
6 \\
2 \\
1 \\
1 \\
7 \\
4 \\
4 \\
3\end{array}$ & $\begin{array}{r}81 \cdot 85 \\
15 \cdot 20 \\
4 \cdot 09 \\
0.79 \\
1.27 \\
0.48 \\
0.82 \\
5 \cdot 07 \\
4.77 \\
0 \cdot 71 \\
0 \cdot 17 \\
0.38 \\
1 \cdot 12 \\
38 \cdot 73 \\
27.90 \\
4.68 \\
4.12 \\
4.43 \\
1.04 \\
12.81 \\
8.75 \\
4.54 \\
2.80\end{array}$ & $\begin{array}{r}90 \\
125 \\
122 \\
127 \\
79 \\
419 \\
122 \\
178 \\
147 \\
142 \\
591 \\
260 \\
179 \\
98 \\
93 \\
128 \\
49 \\
23 \\
96 \\
55 \\
46 \\
88 \\
107\end{array}$ & $\begin{array}{r}71 \\
75 \\
39 \\
2 \\
1 \\
47 \\
2 \\
81 \\
59 \\
2 \\
8 \\
3 \\
20 \\
69 \\
61 \\
47 \\
5 \\
0 \\
1 \\
22 \\
12 \\
24 \\
22\end{array}$ & $\begin{array}{r}114 \\
195 \\
285 \\
706 \\
438 \\
1513 \\
680 \\
337 \\
302 \\
788 \\
3290 \\
1445 \\
647 \\
135 \\
137 \\
279 \\
175 \\
126 \\
534 \\
113 \\
117 \\
225 \\
313\end{array}$ \\
\hline
\end{tabular}

personnel who were asked to classify each department or job title into several major exposure categories by chemical. With this broad exposure classification, it was possible to identify the potential exposures of the cohort members through their work histories. Because little industrial hygiene data existed in the past, it was thought that it would not be possible to assign any numerical exposure levels. Thus a worker was assumed to be either exposed or not exposed to a specific chemical, on a routine or non-routine basis.

Cause-specific mortality analysis was carried out for departments at all four plants with common exposures. These exposures included DBCP, TMCB, TRIS, PBB, other organic and inorganic bromides, and DDT. For these analyses, person years started only after the specific exposures.

\section{$D B C P$}

Workers involved in the production of trimethylene chlorobromide (TMCB) were potentially exposed to DBCP, a trace contaminant. There were 1034 workers at the four plants potentially exposed to DBCP who could be grouped into either routine (production, quality control, shipping) or nonroutine (research, maintenance, transportation) potential exposure categories.

Table 3 summarises the cause-specific mortality experience of these 1034 male workers. The total mortality was less than expected (SMR $=90)$. In this group cancer mortality was slightly raised. The excess appeared to have come from lung cancer, but was not statistically significant at the 0.05 level. In fact, none of the computed cause-specific SMRs was statistically significant.

Eight deaths from diseases of the circulatory system were found among workers potentially exposed to $\mathrm{DBCP}$ on a routine basis in the production departments at the larger Michigan plant (plant A). The expected deaths were only 2.91 ; and the cor-

Table 4 Observed and expected deaths by cause, SMRs, and their $95 \%$ confidence limits for male workers potentially exposed to DBCP on a routine basis in TMBC production departments at plant $A(n=238$, person-years $=1896 \cdot 6)$

\begin{tabular}{|c|c|c|c|c|c|}
\hline Cause of death (8th ICDA) & $\begin{array}{l}\text { Observed } \\
\text { deaths }\end{array}$ & $\begin{array}{l}\text { Expected } \\
\text { deaths }\end{array}$ & $S M R$ & $\begin{array}{l}\text { Lower } \\
\text { limit }\end{array}$ & $\begin{array}{l}\text { Upper } \\
\text { limit }\end{array}$ \\
\hline $\begin{array}{l}\text { All causes } \\
\text { Diseases of circulatory system (393-398) } \\
\text { Arteriosclerotic heart disease (inc CHD) (410-413) } \\
\text { Cerebrovascular disease (430-438) } \\
\text { Accidents, poisonings, and violence (E800-E999) } \\
\text { Accidents (800-949) } \\
\text { Motor vehicle accidents (810-827) } \\
\text { Suicide (950-959) }\end{array}$ & $\begin{array}{r}12 \\
8 \\
6 \\
1 \\
3 \\
2 \\
2 \\
1\end{array}$ & $\begin{array}{l}7 \cdot 85 \\
2 \cdot 91 \\
2 \cdot 17 \\
0 \cdot 30 \\
2 \cdot 16 \\
1 \cdot 46 \\
0 \cdot 83 \\
0.44\end{array}$ & $\begin{array}{l}153 \\
275^{*} \\
277^{*} \\
336 \\
139 \\
137 \\
241 \\
230\end{array}$ & $\begin{array}{r}79 \\
118 \\
101 \\
4 \\
28 \\
15 \\
27 \\
3\end{array}$ & $\begin{array}{r}267 \\
541 \\
602 \\
1871 \\
406 \\
494 \\
870 \\
1277\end{array}$ \\
\hline
\end{tabular}

*Statistically significant at 0.05 level. 
responding SMR was 275 , significant at the 0.05 level (table 4). The excess appeared to have come from arteriosclerotic heart disease.

Other analysis, including the group exposed on a non-routine basis, did not show any difference from the total DBCP group (table 3), and are not reported here.

\section{TRIS}

Departments at the Michigan and Arkansas plants were classified according to either routine or nonroutine exposure to TRIS. Mortality analysis showed no difference between the two groups, and only the combined results are reported here.

Only 628 male workers were ever employed in those departments with potential exposure to TRIS. Thirty six deaths were observed (34.96 expected), with seven due to cancer (6.64 expected) (table 5). Neither of the deviations from the expected was statistically significant. There was a slight, but not significant, increase in mortality from diseases of the circulatory system (19 observed $v 15.66$ expected). It is evident that no adverse mortality was observed in this group. Further departmental analysis of the potential TRIS-exposed group showed no significant findings.

\section{$P B B$}

Potential exposure to $\mathrm{PBB}$ was characterised as routine or non-routine. Of the 91 individuals who were potentially exposed to PBB on a routine basis, none died during the study period. Potentially exposed to PBB on a non-routine basis were 237 male workers. Only two deaths were observed in this second group, although 6.36 were expected. One was due to cancer of the large intestine, which is 10 times greater than the $0 \cdot 10$ expected (SMR = 1007, non-significant). The other death was coded as arteriosclerotic heart disease.

When mortality was analysed by department, 87 people who worked in the research laboratories were found to be potentially exposed to PBB nonroutinely. One case of cancer of the large intestine was observed, compared with an expected of $0 \cdot 01$. Statistically speaking, the corresponding SMR is 8039 , which is significant at the 0.05 level. Since there was only one case, however, this statistical finding must be viewed with caution.

Other organic and inorganic brominated compounds Brominated compounds include both organic and inorganic compounds, such as methyl bromide, ethyl bromide, bromochlorobenzene, polybrominated biphenyls, chlorobromomethane, sodium bromide, potassium bromide, and hydrogen bromide.

Among the 655 individuals potentially exposed to other organic brominated compounds, 51 deaths were observed, higher than the expected $44 \cdot 77$. The overall SMR of 114, however, is not significant (table 6). Cancer mortality was also raised (10 observed $v 7.86$ expected), but the excess was not significant. Two deaths were due to cancer of the testis, and the SMR was $1799(p<0.05)$. This was the only statistically significant result in the organic brominated chemicals group. A detailed case investigation on these two deaths from testicular cancer will be given in the discussion and conclusions section.

Among the 199 individuals identified as having worked with inorganic brominated compounds, 43 deaths occurred. The overall SMR of 111 was slightly, but not significantly, higher than expected

Table 5 Observed and expected deaths by cause SMRs and their $95 \%$ confidence limits for male workers potentially exposed to TRIS on a routine or non-routine basis at all four plants $(n=628$, person-years $=5522 \cdot 1)$

\begin{tabular}{|c|c|c|c|c|c|}
\hline Cause of death (8th ICDA) & $\begin{array}{l}\text { Observed } \\
\text { deaths }\end{array}$ & $\begin{array}{l}\text { Expected } \\
\text { deaths }\end{array}$ & $S M R$ & $\begin{array}{l}\text { Lower } \\
\text { limit }\end{array}$ & $\begin{array}{l}\text { Upper } \\
\text { limit }\end{array}$ \\
\hline $\begin{array}{l}\text { All causes } \\
\text { All cancers (140-209) } \\
\text { Cancer of buccal cavity and pharynx }(140-149) \\
\text { Cancer of digestive system }(150-159) \\
\text { Cancer of large intestine }(153) \\
\text { Cancer of pancreas }(157) \\
\text { Cancer of respiratory system }(160-163) \\
\text { Cancer of lung }(162-163) \\
\text { Cancer of testis }(186) \\
\text { Cancer of bladder }(188) \\
\text { Diabetes mellitus (250) } \\
\text { Diseases of circulatory system (393-398) } \\
\text { Arteriosclerotic heart disease (inc CHD) (410-413) } \\
\text { Cerebrovascular disease (430-438) } \\
\text { Non-malignant respiratory disease (470-527) } \\
\text { Accidents, poisonings, and violence (E800-E999) } \\
\text { Accidents (800-949) } \\
\text { Motor vehicle accidents (810-827) } \\
\text { Suicide (950-959) }\end{array}$ & $\begin{array}{r}36 \\
7 \\
1 \\
2 \\
1 \\
1 \\
2 \\
1 \\
1 \\
1 \\
1 \\
19 \\
14 \\
4 \\
1 \\
5 \\
4 \\
4 \\
1\end{array}$ & $\begin{array}{r}34.96 \\
6.64 \\
0.23 \\
1.69 \\
0.54 \\
0.35 \\
2.32 \\
2.19 \\
0.08 \\
0.15 \\
0.47 \\
15.66 \\
11.64 \\
1.72 \\
1.73 \\
6.25 \\
4.17 \\
2.23 \\
1.37\end{array}$ & $\begin{array}{r}103 \\
105 \\
442 \\
118 \\
186 \\
183 \\
86 \\
46 \\
1242 \\
655 \\
211 \\
121 \\
120 \\
233 \\
58 \\
80 \\
96 \\
179 \\
73\end{array}$ & $\begin{array}{r}72 \\
42 \\
6 \\
13 \\
2 \\
4 \\
10 \\
1 \\
16 \\
9 \\
3 \\
73 \\
66 \\
63 \\
1 \\
26 \\
26 \\
48 \\
1\end{array}$ & $\begin{array}{r}143 \\
217 \\
2461 \\
427 \\
1036 \\
1575 \\
311 \\
254 \\
6912 \\
3647 \\
1174 \\
189 \\
202 \\
596 \\
323 \\
187 \\
245 \\
459 \\
407\end{array}$ \\
\hline
\end{tabular}


Table 6 Observed and expected deaths by cause SMRs and their $95 \%$ confidence limits for male workers potentially exposed to other brominated organic chemicals $(n=665$, person-years $=7376.0)$

\begin{tabular}{|c|c|c|c|c|c|}
\hline Cause of death (8th ICDA) & $\begin{array}{l}\text { Observed } \\
\text { deaths }\end{array}$ & $\begin{array}{l}\text { Expected } \\
\text { deaths }\end{array}$ & $S M R$ & $\begin{array}{l}\text { Lower } \\
\text { limit }\end{array}$ & $\begin{array}{l}\text { Upper } \\
\text { limit }\end{array}$ \\
\hline $\begin{array}{l}\text { All causes } \\
\text { Infective and parasitic diseases }(000-139) \\
\text { All cancers }(140-209) \\
\text { Cancer of digestive system }(150-159) \\
\text { Cancer of large intestine }(153) \\
\text { Cancer of pancreas (157) } \\
\text { Cancer of respiratory system }(160-163) \\
\text { Cancer of lung }(162-163) \\
\text { Cancer of prostate }(185) \\
\text { Cancer of testis (186) } \\
\text { Cancer of brain (191) } \\
\text { Lymphatic and haematopoietic cancer (200-205) } \\
\text { Leukaemia and aleukaemia }(204-207) \\
\text { Diseases of nervous system and sense organs (390-458) } \\
\text { Diseases of circulatory system }(393-398) \\
\text { Arteriosclerotic heart disease (inc CHD) (410-413) } \\
\text { Cerebrovascular disease (430-438) } \\
\text { Non-malignant respiratory disease (470-527) } \\
\text { Diseases of digestive system (530-587) } \\
\text { Cirrhosis of liver (581) } \\
\text { Diseases of genitourinary system (580-629) } \\
\text { Accidents, poisonings, and violence (E800-E999) } \\
\text { Accidents (800-949) } \\
\text { Motor vehicle accidents (810-827) } \\
\text { Suicide (950-959) }\end{array}$ & $\begin{array}{r}51 \\
1 \\
10 \\
2 \\
1 \\
1 \\
3 \\
3 \\
1 \\
2 \\
1 \\
1 \\
1 \\
1 \\
25 \\
18 \\
3 \\
1 \\
2 \\
1 \\
1 \\
8 \\
6 \\
6 \\
2\end{array}$ & $\begin{array}{r}44.77 \\
0.74 \\
7.86 \\
2.20 \\
0.66 \\
0.41 \\
2.43 \\
2.28 \\
0.36 \\
0.11 \\
0.33 \\
0.94 \\
0.38 \\
0.46 \\
20.20 \\
13.92 \\
1.52 \\
2.05 \\
2.45 \\
1.35 \\
0.70 \\
8.20 \\
5.68 \\
2.99 \\
1.72\end{array}$ & $\begin{array}{c}114 \\
136 \\
127 \\
91 \\
152 \\
243 \\
123 \\
131 \\
281 \\
1799^{*} \\
305 \\
106 \\
265 \\
216 \\
124 \\
129 \\
119 \\
49 \\
82 \\
74 \\
142 \\
98 \\
106 \\
200 \\
117\end{array}$ & $\begin{array}{r}85 \\
2 \\
61 \\
10 \\
2 \\
3 \\
25 \\
26 \\
4 \\
202 \\
2 \\
1 \\
3 \\
3 \\
80 \\
77 \\
24 \\
1 \\
9 \\
1 \\
2 \\
42 \\
39 \\
73 \\
13\end{array}$ & $\begin{array}{r}150 \\
755 \\
234 \\
328 \\
847 \\
1354 \\
361 \\
384 \\
1562 \\
6495 \\
1694 \\
589 \\
1474 \\
1203 \\
183 \\
204 \\
348 \\
271 \\
294 \\
411 \\
792 \\
192 \\
230 \\
436 \\
421\end{array}$ \\
\hline
\end{tabular}

*Statistically significant at $0 \cdot 05$ level.

(table 7). A total of 13 deaths was attributed to cancer, but only 7.09 were expected based on the United States experience. The computed SMR for all cancers was $183(p=0 \cdot 05$, lower limit $=98)$. The excess came from respiratory cancer: seven observed $v \quad 2.27$ expected. The corresponding respiratory cancer SMR was $308(\mathrm{p}<0.05)$. Except for this significant finding, all other computed cause-specific SMRs were within the expected range among those potentially exposed to inorganic brominated compounds.

\section{$D D T$}

DDT was at one time manufactured at plant A. According to the available work histories, 740 individuals were identified as having worked in DDT

Table 7 Observed and expected deaths by cause, SMRs, and their $95 \%$ confidence limits for male workers potentially exposed to brominated inorganic chemicals $(n=199$, person-years $=5457 \cdot 5)$

\begin{tabular}{|c|c|c|c|c|c|}
\hline Cause of death (8th ICDA) & $\begin{array}{l}\text { Observed } \\
\text { deaths }\end{array}$ & $\begin{array}{l}\text { Expected } \\
\text { deaths }\end{array}$ & $S M R$ & $\begin{array}{l}\text { Lower } \\
\text { limit }\end{array}$ & $\begin{array}{l}\text { Upper } \\
\text { limit }\end{array}$ \\
\hline $\begin{array}{l}\text { All causes } \\
\text { Infective and parasitic diseases }(000-139) \\
\text { All cancers }(140-209) \\
\text { Cancer of digestive system }(150-159) \\
\text { Cancer of stomach }(151) \\
\text { Cancer of pancreas }(157) \\
\text { Cancer of respiratury system }(160-163) \\
\text { Cancer of lung }(162-163) \\
\text { Cancer of prostate }(185) \\
\text { Cancer of kidney }(189) \\
\text { Lymphatic and haematopoietic cancer (200-209) } \\
\text { Diabetes mellitus (250) } \\
\text { Diseases of circulatory system (393-398) } \\
\text { Arteriosclerotic heart disease (inc CHD) (410-413) } \\
\text { Cerebrovascular disease (430-438) } \\
\text { Non-malignant respiratory disease (470-527) } \\
\text { Pneumonia (480-486) } \\
\text { Diseases of digestive system (530-587) } \\
\text { Accidents, poisonings, and violence (E800-E999) } \\
\text { Accidents (800-949) } \\
\text { Motor vehicle accidents (810-827) } \\
\text { Suicide (950-959) }\end{array}$ & $\begin{array}{r}43 \\
1 \\
13 \\
2 \\
1 \\
1 \\
7 \\
6 \\
1 \\
1 \\
1 \\
2 \\
17 \\
13 \\
1 \\
2 \\
2 \\
2 \\
6 \\
4 \\
2 \\
2\end{array}$ & $\begin{array}{r}38.60 \\
0.74 \\
7.09 \\
2.05 \\
0.44 \\
0.39 \\
2.27 \\
2.14 \\
0.37 \\
0.18 \\
0.75 \\
0.54 \\
19.24 \\
13.33 \\
2.44 \\
1.99 \\
0.80 \\
2.08 \\
4.78 \\
3.37 \\
1.59 \\
1.06\end{array}$ & $\begin{array}{r}111 \\
136 \\
183 \\
97 \\
230 \\
259 \\
208^{*} \\
281^{*} \\
269 \\
548 \\
133 \\
370 \\
88 \\
98 \\
41 \\
100 \\
252 \\
96 \\
126 \\
119 \\
125 \\
188\end{array}$ & $\begin{array}{r}81 \\
2 \\
98 \\
11 \\
3 \\
3 \\
123 \\
103 \\
4 \\
7 \\
2 \\
42 \\
51 \\
52 \\
1 \\
11 \\
28 \\
11 \\
46 \\
32 \\
14 \\
21\end{array}$ & $\begin{array}{r}150 \\
754 \\
314 \\
352 \\
1278 \\
1442 \\
634 \\
612 \\
1498 \\
3046 \\
738 \\
1336 \\
141 \\
167 \\
228 \\
363 \\
908 \\
347 \\
273 \\
304 \\
453 \\
678\end{array}$ \\
\hline
\end{tabular}

*Statistically significant at 0.05 level 
Table 8 Observed and expected deaths by cause, SMRs, and their $95 \%$ confidence limits for male workers exposed to $D D T(n=740$, person-years $=17186 \cdot 9)$

\begin{tabular}{|c|c|c|c|c|c|}
\hline Cause of death (8th ICDA) & $\begin{array}{l}\text { Observed } \\
\text { deaths }\end{array}$ & $\begin{array}{l}\text { Expected } \\
\text { deaths }\end{array}$ & $S M R$ & $\begin{array}{l}\text { Lower } \\
\text { limit }\end{array}$ & $\begin{array}{l}\text { Upper } \\
\text { limit }\end{array}$ \\
\hline $\begin{array}{l}\text { All causes } \\
\text { Infective and parasitic diseases }(000-139) \\
\text { All cancers }(140-209) \\
\text { Cancer of buccal cavity and pharynx }(140-149) \\
\text { Cancer of digestive system }(150-159) \\
\text { Cancer of stomach (151) } \\
\text { Cancer of large intestine }(153) \\
\text { Cancer of rectum (154) } \\
\text { Cancer of respiratory system }(160-163) \\
\text { Cancer of lung (162-163) } \\
\text { Cancer of testis (186) } \\
\text { Cancer of bladder (188) } \\
\text { Lymphatic and haematopoietic cancer (200-205) } \\
\text { Leukaemia and aleukaemia (204-207) } \\
\text { Diseases of nervous system and sense organs (390-458) } \\
\text { Diseases of circulatory system (393-398) } \\
\text { Arteriosclerotic heart disease (inc CHD) (410-413) } \\
\text { Cerebrovascular disease (430-438) } \\
\text { Non-malignant respiratory disease (470-527) } \\
\text { Pneumonia (480-486) } \\
\text { Emphysema (492) } \\
\text { Diseases of digestive system (530-587) } \\
\text { Cirrhosis of liver (581) } \\
\text { Diseases of genitourinary system (580-629) } \\
\text { Accidents, poisonings, and violence (E800-E999) } \\
\text { Accidents (800-949) } \\
\text { Motor vehicle accidents (810-827) } \\
\text { Suicide ( } 950-959)\end{array}$ & $\begin{array}{r}112 \\
1 \\
19 \\
1 \\
3 \\
1 \\
1 \\
1 \\
10 \\
9 \\
1 \\
1 \\
3 \\
2 \\
3 \\
54 \\
42 \\
5 \\
5 \\
1 \\
1 \\
5 \\
1 \\
1 \\
20 \\
12 \\
8 \\
7\end{array}$ & $\begin{array}{r}112.83 \\
1.81 \\
20.08 \\
0.68 \\
5.45 \\
1.10 \\
1.68 \\
0.64 \\
6.43 \\
6.05 \\
0.26 \\
0.49 \\
2.40 \\
0.95 \\
1.14 \\
52.85 \\
37.19 \\
6.57 \\
5.47 \\
2.25 \\
1.27 \\
6.31 \\
3.52 \\
1.71 \\
18.23 \\
12.96 \\
6.57 \\
3.82\end{array}$ & $\begin{array}{r}99 \\
55 \\
95 \\
147 \\
55 \\
91 \\
60 \\
156 \\
156 \\
149 \\
392 \\
203 \\
125 \\
211 \\
263 \\
102 \\
113 \\
76 \\
91 \\
44 \\
79 \\
79 \\
28 \\
176 \\
110 \\
93 \\
122 \\
183\end{array}$ & $\begin{array}{r}82 \\
1 \\
57 \\
2 \\
11 \\
1 \\
1 \\
2 \\
74 \\
68 \\
5 \\
3 \\
25 \\
24 \\
53 \\
77 \\
81 \\
25 \\
29 \\
1 \\
1 \\
26 \\
0 \\
35 \\
67 \\
48 \\
52 \\
73\end{array}$ & $\begin{array}{l}119 \\
307 \\
148 \\
819 \\
161 \\
508 \\
332 \\
886 \\
286 \\
282 \\
2180 \\
1129 \\
365 \\
763 \\
769 \\
133 \\
153 \\
178 \\
213 \\
247 \\
440 \\
185 \\
158 \\
514 \\
169 \\
162 \\
240 \\
378\end{array}$ \\
\hline
\end{tabular}

production departments. Table 8 presents the cause-specific SMRs for these workers. The total mortality was exactly what we would expect (112 observed $v 112.83$ expected). Cancer mortality was slightly less than the expectation. When specific sites were examined, however, there was an excess in respiratory cancer. With 10 observed deaths, the SMR of 156 was not statistically significant. It should be pointed out here that many individuals in this group who were potentially exposed to DDT were also potentially exposed to other chemicals, including inorganic brominated compounds. It may well be that the respiratory cancer mortality excess in the DDT group simply reflects the statistical association found earlier among workers potentially exposed to inorganic brominated compounds. Table 8 shows no significant adverse cause-specific mortality among the group potentially exposed to DDT.

\section{CASE-CONTROL ANALYSIS OF THE RESPIRATORY CANCER DEATHS}

In the analysis above we have examined several chemicals suspected in relation to respiratory cancers using the SMR approach. The advantage of this approach is that the subcohorts were defined a priori and, as pointed out by Doll, ${ }^{4}$ there are fewer opportunities for introducing bias and the results can be expressed naturally in terms of probability of dying from a specific cause. The major disadvantage is that such a study is very time consuming, since relevant information must be coded for the entire cohort so that different subcohorts of interest can be identified. Furthermore, without prior knowledge, the responsible exposures may not have been included in the study design. One remedy, first suggested by Mantel, is to perform case-control analysis within a cohort study. ${ }^{5}$ To investigate further the excess in respiratory cancer, such a case-control analysis was performed in the present study. Only part of the analysis is reported here.

The cases are the 46 deaths from respiratory cancer from plant $\mathbf{A}$. The control group was chosen from white male workers who died during the same period from other causes of death. All deaths from cancer, non-malignant respiratory deaths, and deaths due to unknown causes were excluded. To control for confounding, several sets of criteria were used. Only the set of interest here is included in this report. Each case had two random controls matched by plant, age at death, and age at hire. The last parameter pertains to the age dependence on biological mechanism in responding to environmental assaults. In addition to an examination of the detailed work history (both departments and job titles) an attempt was made to collect smoking histories by reviewing available original employment records and talking to long term employees and supervisors familiar with the workforce. Unfortunately, ascertainment of smoking history was incomplete: only $20 \%$ were definitely known as 
Table 9 Case-control analysis of 46 deaths from respiratory cancer and 92 matched controls in a cohort potentially exposed to brominated chemicals

\begin{tabular}{|c|c|c|c|c|c|c|c|}
\hline \multirow[t]{2}{*}{ Study variable } & \multicolumn{2}{|c|}{ Cases exposed } & \multicolumn{2}{|c|}{ Controls exposed } & \multirow{2}{*}{\multicolumn{2}{|c|}{ Odds ratio $\chi^{2}$}} & \multirow[t]{2}{*}{$p$} \\
\hline & No & $\%$ & $N o$ & $\%$ & & & \\
\hline $\begin{array}{l}\text { Inorganic bromides } \\
\text { DDT } \\
\text { Magnesium oxide } \\
\text { Maintenance departments }\end{array}$ & $\begin{array}{r}7 \\
10 \\
8 \\
16\end{array}$ & $\begin{array}{l}15 \\
22 \\
20 \\
35\end{array}$ & $\begin{array}{r}2 \\
25 \\
17 \\
21\end{array}$ & $\begin{array}{r}2 \\
27 \\
18 \\
23\end{array}$ & $\begin{array}{l}7 \cdot 00 \\
0 \cdot 74 \\
1 \cdot 08 \\
1 \cdot 73\end{array}$ & $\begin{array}{l}6 \cdot 13 \\
0.26 \\
0.01 \\
1 \cdot 56\end{array}$ & $\begin{array}{l}0.01 \\
0.61 \\
0.66 \\
0.21\end{array}$ \\
\hline $\begin{array}{l}\text { Duration of employment: } \\
<1 \text { month } \\
1-11 \text { months } \\
1-4 \text { years } \\
5-14 \text { years } \\
\geqslant 15 \text { years }\end{array}$ & $\begin{array}{r}9 \\
15 \\
13 \\
6 \\
3\end{array}$ & $\begin{array}{r}20 \\
33 \\
28 \\
13 \\
7\end{array}$ & $\begin{array}{r}19 \\
28 \\
22 \\
15 \\
8\end{array}$ & $\begin{array}{r}21 \\
30 \\
24 \\
16 \\
9\end{array}$ & - & $0 \cdot 13$ & 0.72 \\
\hline
\end{tabular}

smokers, while no definitive statement could be made on the rest.

Table 9 presents the case-control analysis. Past exposures to inorganic brominated chemicals, DDT, magnesium oxide, or maintenance departments, together with duration of employment among the cases and controls were analysed by the MantelHaenszel $\chi^{2}$ and its extension. ${ }^{67}$ Only one significant positive association was found. The odds ratio (as an approximate relative risk) for respiratory cancer and inorganic bromides was $7.00\left(\chi^{2}=6.13, p<0.01\right)$. The odds ratio for maintenance departments was 1.73 , but this was not statistically significant.

\section{Discussion and conclusions}

The overall mortality of this cohort of male chemical workers at the bromination plants was $12 \%$ less than would have been expected from a group of United States white men of similar age during the same period. This mortality deficit is statistically significant at the 0.05 level.

For the entire cohort, the observed mortality from cancer of all sites was similar to expected. When site-specific cancer mortality was examined, a significant deficit was found in cancer of the digestive system. Forty six deaths from respiratory cancer were observed, compared with an expected 34.07; this excess is of border line statistical significance $(p=0 \cdot 05)$. All other site-specific cancer SMRs are within the expected range.

Diabetes mellitus was the only cause of death with a statistically significant excess for the cohort as a whole. There were 19 deaths from this condition, when only 8.65 were expected $(S M R=220, p<$ $0 \cdot 01)$ using United States white men as the standard. Diabetes mortality rates vary considerably by state. For men, the average annual age adjusted Michigan diabetes mortality rate for 1969-71 ranked third in the nation, and was $47 \%$ higher than the national average. ${ }^{8}$ In view of this considerable regional dif- ference, it would be more appropriate to compute an SMR based on Michigan rates. Using the 1970 Michigan white male age specific rates as the standard, a total of 13.81 deaths from diabetes would have been expected for the entire cohort as a whole, and the corresponding SMR is 138 (not significant). Therefore, the significant excess of deaths from diabetes observed in the cohort as a whole may be attributed, at least in part, to the regional variation between Michigan and the United States. It should, however, be pointed out that, even after adjusting for regional variation, there was still a nonsignificant excess for the entire cohort. Examination showed that $80 \%$ of those who had died from diabetes mellitus were hired during the early and mid1940s. Additional analysis confirmed that those hired before 1945 experienced a diabetes mellitus SMR of 364 ( $p<0.01)$. Further investigation did not show any changes in processes or chemicals used around 1945. An examination of the list of chemicals presented at the plants did not show any known pancreatic toxins. We are not aware of any occupational hazards that would induce diabetes mellitus, although chromium is mentioned as one of the risk factors in a recent National Institutes of Health publication. Welders are potentially exposed to chromium, but none of those who had died from diabetes was specifically engaged in welding. Based on our current knowledge, the major aetiological factors for diabetes are genetics and obesity. These decedents probably represented individuals rejected by the military for health reasons during the war.

The overall mortality deficit in the entire cohort discussed above comes primarily from diseases of the circulatory system $(\mathrm{SMR}=83, \mathrm{p}<0 \cdot 01)$. This deficit in the entire cohort, however, would not exclude the possibility that some of the subgroups would experience adverse mortality from diseases of the circulatory system. For the entire cohort, mortality from pneumonia and diseases of the digestive system was also significantly less than that of the 
overall Unites States white male population.

Among the male TMBC production workers potentially exposed to $\mathrm{DBCP}$ on a routine basis at plant $\mathrm{A}$, a significant mortality excess from diseases of the circulatory system (primarily from arteriosclerotic heart disease including coronary heart disease) was detected. When the appropriate Michigan age specific mortality rates for diseases of the circulatory system were used, the SMR increased from 275 (based on United States) to 323 (based on Michigan, $p<0.01$ ). Many risk factors are known to be associated with an increased incidence of diseases of the circulatory system. The key risk factors seem to be related to the macroenvironment, and include diet, behaviour pattern, physical activity, genetics, cigarette smoking, water hardness, and life style. Several occupational agents have also been implicated, however, although the impact of these occupational agents is much smaller than that of the risk factors in the macroenvironment. Animal studies have shown that polyhalogenated hydrocarbons are oestrogenic and tend to bind to oestrogen receptors. It has also been reported that people occupationally exposed to pesticides have raised HDL cholesterol and triglycerides. ${ }^{10}$ Thus the mortality excess from diseases of the circulatory system found here is consistent with the known toxicity of chemicals with similar structures.

One of the 87 individuals who worked in the research laboratory with potential exposure to PBB died from cancer of the large intestine; fewer than 0.01 deaths from this cause were expected. The corresponding SMR is significant. Because only one case was involved, however, the finding is difficult to interpret, and is most likely due to chance.

Among the 665 individuals exposed to other organic bromides, two deaths were attributed to testicular cancer but only $0 \cdot 11$ was expected. The risk was almost 18 times higher than the expected (SMR $=1799, \mathrm{p}<0.05)$. Both men died very young $(17$ and 33), which is not unusual for victims of testicular cancer. Both were hired at the same time and were potentially exposed to methyl bromide around the same time. Based on the work histories, methyl bromide is the only common potential exposure, although the second individual worked later in the research laboratory with potential exposure to a multitude of chemicals. It must be emphasised, however, that there were only two cases and the statistical variability is quite large.

Several risk factors in testicular cancer have been identified, including a history of undescended testis, mumps orchitis, or testicular injury, prenatal exposure to hormones such as oestradiol and diethylstilboestrol, prenatal radiation, and use of jockey type shorts. ${ }^{11}$ Unfortunately it was not possible to obtain clinical records to verify whether any of these factors were involved. Nor was it possible to obtain the histological classification of the tumours observed in these two cases. Based on the recorded work histories, however, the only common potential exposure was organic bromide (methyl bromide). Other organic brominated compounds such as DBCP or ethylene dibromide have been shown as testicular toxins or suppressors of spermatogenesis. ${ }^{12-16}$ These reports on the testicular toxicity of similar compounds suggest that the statistical association found here between methyl bromide and testicular cancer should be verified in a larger population similarly exposed, or the present study should be updated in the near future to include more person-years.

A total of 199 male workers were potentially exposed to inorganic brominated chemicals. Seven deaths were due to respiratory cancer, when only 2.27 were expected. The SMR is 308 and statistically significant. According to the National Cancer Institute, the annual Michigan lung cancer death rate for white men during 1950-69 was only slightly higher than the national average (39.09 per 100000 $v 37.98$ per 100000$).{ }^{17}$ Thus regional variation is not a confounding factor here. All seven individuals were hired during the 1940s. Three worked for under six months and another for under two years. A case-control (retrospective) analysis on the deaths from respiratory cancer confirmed the positive association between inorganic bromides and respiratory cancer. Unfortunately, a more specific agent could not be identified.

Many risk factors have been identified with an increase in the incidence of lung cancer, of which the most common are cigarette smoking, radiation, and asbestos. Unfortunately clinical records were not available for these individuals so that the pathogenesis of these deaths could not be better understood. Although several inorganic bromides have been shown as respiratory irritants, no carcinogenicity has been suspected. As such, this finding should be viewed as preliminary and as a hypothesis for testing by additional investigations in similarly exposed populations, or by updating the mortality experience of the present cohort in the future.

In closing, it should be pointed out that there are several limitations in the present study, most of which are typical of historical mortality study of industrial populations. ${ }^{18}$ (1) Although the percentage lost to follow up and the proportion of the outstanding death certificates were reasonably low, it was possible, but unlikely, that deaths from certain rare causes were missed. (2) A termination date was missing for several workers for whom the duration of employment might have been over or underesti- 
mated. (3) In several cases, work histories in the employment records did not provide enough details to pinpoint specific exposures. (4) Historical data on exposure levels were inadequate for the chemicals under investigation. Thus no quantification of exposure was possible. (5) Many of the workers were potentially exposed to a multitude of chemicals, and it was impossible to examine mortality by "pure" exposure. (6) For several conditions, the number of study subjects in some of the subgroups was smaller than desirable, and it was difficult to draw definitive conclusions. (7) Being a mortality study, the investigation not only inherited all the problems asseciated with death certificates but also suffered from lack of in-depth clinical information . (8) Employment other than that with the existing company was not considered. Nor was it feasible to include smoking history in the analysis. Despite these limitations, the study has identified several potential health problems in the cohort. We recommend that this study be updated in the future. A longer observation period will not only increase the statistical power of the study but also establish any trend in mortality, if one exists, in the cohort.

We thank Professor Brian MacMahon of Harvard University, Dr Philip Landrigan and Mr David Brown of the National Institute for Occupational Safety and Health, and Dr Thomas H Milby of Environmental Health Associates for reviewing an earlier draft of this report and for making several constructive comments. This study was sponsored by Velsicol Chemical Corporation.

Requests for reprints to: Dr Wong, Environmental Health Associates, 2150 Shattuck Avenue, Suite 414, Berkeley, CA 94704.

\section{References}

' Wong O. An epidemiologic study of workers potentially exposed to brominated chemicals: with a discussion of multifactor adjustment. Banbury report No. 9. Qualifications of occupation cancer. Cold Spring Harbor Laboratory, 1981: 359-78.

${ }^{2}$ World Health Organisation. International classification of diseases. 1979 revision. Geneva: WHO, 1978.

${ }^{3}$ Monson RR. Analysis of relative survival and proportional mortality. Computers and Biomedical Research 1974;7:325-32. (An updated version of this program was used in the present study.)

4 Doll R. Retrospective and prospective studies. In: Witts LJ, ed. Medical surveys and clinical trials. London: Oxford University Press, 1964:96-7.

${ }^{5}$ Mantel N. Synthetic retrospective studies and related topics. Biometrics 1973;29:479-86.

- Mantel N, Haenszel W. Statistical aspects of the analysis of data from retrospective studies of diseases. JNCI 1959;22:719-48.

' Mantel N. Chi-square tests with one degree of freedom: extensions of the Mantel-Haenszel procedure. JASA 1963;58:690-700.

${ }^{8}$ National Commission on Diabetes. Report. Vol III, part 1. Washington: Department of Health Education and Welfare, 1976. (DHEW Publication No (NIH) 76-1021, 1976.)

${ }^{9}$ Public Health Service, National Institutes of Health. Diabetes data. (Compiled 1977.) Washington: NIH, 1979. (NIH Publication No 79-1468, 1979.)

${ }^{10}$ National Heart, Lung and Blood Institute. Report of the working group on heart disease epidemiology. Washington: 1979. National Institutes of Health. (NIH publication No 79-1667, 1979.)

" Longhlin JE, Robboy SJ, Morrison AS. Risk factors for cancer of the testis. N Engl J Med 1980;303:112-3.

${ }_{12}$ Amir D, Voleani R. Effect of dietary ethylene dibromide on bull semen. Nature 1965;206:99-100.

${ }^{13}$ Edwards K, Jackson H, Jones AR. Studies with alkylating esters. II. A chemical interpretation through metabolic studies of the anti-fertility effects of ethylene dimethanesulphonate and ethylene dibromide. Biochem Pharmacol 1970;19:1783-9.

14 Wong O, Utidjian HMD, Karten VS. Retrospective evaluation of reproductive performance of workers exposed to ethylene dibromide (EDB). JOM 1979;21:98-106.

${ }^{15}$ Whorton D, Krauss, RM, Marshall S, Milby TH. Infertility in male pesticide workers. Lancet 1977;ii:1259-61.

${ }^{16}$ Milby TH, Whorton D. Epidemiological assessment of occupationally related, chemically induced sperm count suppression. JOM 1980;22:77-82.

${ }^{17}$ Mason TJ, McKay FW. US cancer mortality by county, 19501969. Washington: Department of Health Education and Welfare, 1974. (DHEW publication No (NIH) 74-615, 1974.)

${ }^{18}$ Wong $\mathrm{O}$. A practical guide for non-epidemiologists. Parts 1 and 2. Occupational Health and Safety 1981;50:31-9, 21-6. 